\title{
Biological Activity of Betulinic Acid: A Review
}

\author{
Mansour Ghaffari Moghaddam ${ }^{1}$, Faujan Bin H. Ahmad ${ }^{2 *}$, Alireza Samzadeh-Kermani ${ }^{1}$ \\ ${ }^{1}$ Department of Chemistry, Faculty of Science, University of Zabol, Zabol, Iran; ${ }^{2}$ Department of Chemistry, Faculty of Science, Uni- \\ versiti Putra Malaysia, Selangor, Malaysia. \\ Email: *aujan@science.upm.edu.my
}

Received January $15^{\text {th }}, 2012$; revised February $18^{\text {th }}, 2012$; accepted March $6^{\text {th }}, 2012$

\begin{abstract}
Betulinic acid is a known natural product which has gained a lot of attention in the recent years since it exhibits a variety of biological and medicinal properties. This review provides the most important biological properties of betulinic acid.
\end{abstract}

Keywords: Betulinic Acid; Betulin; Triterpene; Natural Product; Medicinal Properties

\section{Introduction}

Betulinic acid, (3 $\beta$-hydroxy-lup-20(29)-en-28-oic acid) (Figure 1) is a naturally occurring pentacyclic lupanetype triterpenoid which exhibits a variety of biological and medicinal properties such as inhibition of human immunodeficiency virus (HIV) [1,2], anti-bacterial [2,3], anti-malarial [4], anti-inflammatory [5-8] anthelmintic [9], antinociceptive [10], anti-HSV-1 [11,12], and anticancer activities [13-16]. Betulinic acid is widely distributed throughout the plant kingdom [17]. The birch tree (Betula spp., Betulaceae) is one of the most widely reported sources of betulinic acid and betulin which can be obtained in considerable quantities [18-20]. Betulinic acid could be also isolated from various sources include Ziziphus spp. (Rhamnaceae) [16,21,22], Syzygium spp. (Myrtaceae) [1,23], Diospyros spp. (Ebenaceae) [24-26] and Paeonia spp. (Paeoniaceae) [27]. The reduced congener of betulinic acid, betulin (3 $\beta$-lup-20(29)-ene-3, 28-diol) (Figure 1), was one of the first natural products isolated in 1788 from the bark of the white birch, Betula alba [28]. This review focuses on the pharmacological properties of betulinic acid.

\section{Anticancer Activity}

Kumar et al. [29] isolated betulinic acid from the methanolic extract of Dillenia indica L. fruits. The methanolic extract showed significant anti-leukemic activity in human leukemic cell lines U937, HL60 and K562. The isolated betulinic acid showed $\mathrm{IC}_{50}$ of values at $13.73,12.84$, $15.27 \mathrm{mg} / \mathrm{ml}$ in U937, HL60 and K562 cell lines, respectively.

\footnotetext{
"Corresponding author.
}

Betulinic acid was isolated from the $\mathrm{MeOH}$ extract of the aerial part of Vietnamese Orthosiphon stamineus and tested for its cytotoxicity towards highly liver metastatic murine colon 26-L5 carcinoma cells [30]. It was found that betulinic acid shows the cytotoxicity with an $\mathrm{ED}_{50}$ value of $75.4 \mu \mathrm{g} / \mathrm{ml}$.

Betulinic acid was obtained from the ethanol extract of Engelhardtia serrata Bl. by bioassay-guided isolation and was tested for its cytotoxic and apoptosis-inducing activities against the K562 cell line [31]. Betulinic acid showed an inhibitory activity on the growth of K562 tumor cell line with $\mathrm{IC}_{50}$ value of $6.25 \mu \mathrm{g} / \mathrm{ml}$ and also induced $35 \%$ apoptosis at $25 \mu \mathrm{g} / \mathrm{ml}$.

Betulinic acid was isolated from the $\mathrm{CHCl}_{3}$ extract of the bark of Bischofia javanica and was evaluated for its inhibitory effects on DNA Topoisomerases (Topos) II activity [32]. Betulinic acid was found to be catalytic inhibitor of Topo II activity with $\mathrm{IC}_{50}$ value of $56.12 \mu \mathrm{M}$ which was comparable to that of $52.38 \mu \mathrm{M}$ for a classic Topo II inhibitor, etoposide. It was suggested that betulinic acid is potent DNA Topo II inhibitor. The $\mathrm{ED}_{50}$ values of betulinic acid and etoposide were found to be 7.19 and $2.59 \mu \mathrm{M}$ against A549 cancer cell line.

Betulinic acid was isolated from the methanol extract of the dried leaves of Nerium oleanderand and was tested for its in vitro anticancer activity on the basis of the cell growth inhibitory activities toward three kinds of human cell lines, i.e. WI-38 fibroblast cells, VA-13 malignant tumor cells, and HepG2 human liver tumor cells [33]. Betulinic acid showed significant cell growth inhibitory to WI-38 cells, moderate cell growth inhibitory activity to VA-13 cells and moderate cell growth inhibitory activity to HepG2 with $\mathrm{IC}_{50}$ values of $1.3,11.6$ and $21 \mu \mathrm{M}$, respectively. 

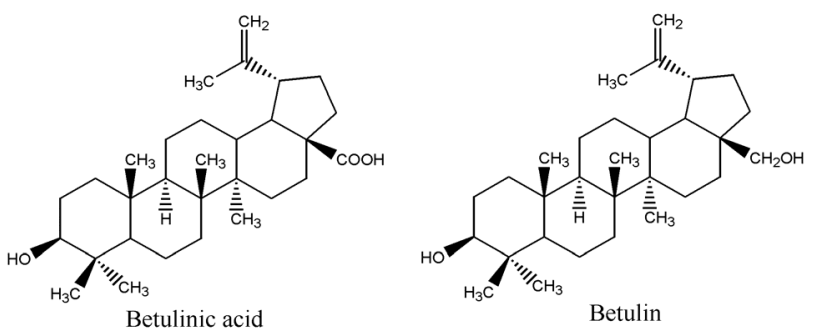

Figure 1. Structures of betulinic acid and betulin.

\section{Anti-HIV Activity}

Betulinic acid was isolated from the $\mathrm{MeOH}$ extract of the leaves of Syzrgium claviflorum by Fujioka et al. [2] and was tested on HIV-1 replication in H9 lymphocyte cells. It was found that betulinic acid shows an inhibitory activity against HIV-1 replication with an $\mathrm{EC}_{50}$ value of 1.4 $\mu \mathrm{M}$ and inhibited uninfected $\mathrm{H} 9$ cell growth with an $\mathrm{IC}_{50}$ value of $13 \mu \mathrm{M}$. This finding prompted them to prepare derivatives of betulinic acid and to evaluate their antiHIV activity.

Theo et al. [34] isolated betulinic acid from the stem bark of Peltophorum africanum, a traditional South African medicinal plant. They evaluated it for the inhibitory activities against $\mathrm{HIV}-1_{\mathrm{NLA}-3}(\mathrm{X} 4-\mathrm{HIV}-1)$ and HIV- $1_{\mathrm{JRCSF}}$ (R5-HIV-1). Betulinic acid inhibited against HIV-1 $1_{\text {NL4-3 }}$ and HIV- $1_{\text {JRCSF }}$ with $\mathrm{IC}_{50}$ values of 0.04 and $0.002 \mu \mathrm{g} / \mathrm{ml}$, respectively. They suggested that betulinic acid could be used as potential therapeutics for HIV-1.

Betulinic acid was isolated from the leaves and twigs of Cratoxylum arborescens and was tested in the HIV-1 RT assay and syncytium assay [35]. Betulinic acid showed anti-HIV-1 activity in the syncytium assay with $\mathrm{IC}_{50}$ value of $9.8 \mu \mathrm{g} / \mathrm{ml}$ and in the RT assay with $\mathrm{IC}_{50}$ of 10.8 $\mu \mathrm{g} / \mathrm{ml}$. The results showed that betulinic acid is the most active of isolated compounds in the syncytium assay.

\section{Anti-Bacterial Activity}

Woldemichael et al. [36] isolated betulinic acid from the $\mathrm{CH}_{2} \mathrm{Cl}_{2}-\mathrm{MeOH}$ extract of the Argentinean legume Caesalpinia paraguariensis Burk and tested it against Bacillus subtilis, methicillin-sensitive and -resistant Staphylococcus aureus, Escherichia coli, and Candida albicans. Betulinic acid was found to be inactive against the tested organisms with MICs (minimum inhibitory concentrations) greater than $128 \mu \mathrm{g} / \mathrm{ml}$.

Betulinic acid was isolated from the crude chloroform bark extract of Syncarpia glomulifera (Myrtaceae) by Setzer et al. [37]. It was found that the crude extract of $S$. glomulifera shows anti-bacterial and cytotoxic activity. They reported that the relatively large abundance $(10 \%$ of the crude extract) and high degree of activity of betulinic acid are responsible for the bioactivity of the crude bark extract.
The stem bark of the Brazilian medicinal plant Zizyphus joazeiro was phytochemically investigated by Schühly et al. [4]. Betulinic acid was isolated from the dichloromethane extract which showed a considerable activity against Gram-positive bacteria.

The anti-bacterial activity of isolated betulinic acid from leaves of Vitex negundo L. was tested against $\mathrm{Ba}$ cillus subtilis and Escherichia coli, by the paper disc method [3]. Betulinic acid did not show any inhibition zone (total area-disc area) against Escherichia coli at concentrations of $1000 \mu \mathrm{g} / \mathrm{disc}, 500 \mu \mathrm{g} / \mathrm{disc}, 250 \mu \mathrm{g} / \mathrm{disc}$ and $125 \mu \mathrm{g} /$ disc. However, betulinic acid showed 18.8 $\mathrm{mm}^{2}$ of inhibition zone against Bacillus subtilis at concentration of $1000 \mu \mathrm{g} / \mathrm{disc}$ while at a concentration of $500 \mu \mathrm{g} / \mathrm{disc}$ and below, the betulinic acid did not show any inhibition zone. Kanamycin was used as a standard compound which showed an inhibition zone of 207.2 $\mathrm{mm}^{2}$ at a concentration of $0.05 \mu \mathrm{g} / \mathrm{ml}$.

The extract of Forsythia suspensa VAHL was studied by Shin et al. [38]. It showed a strong inhibition of the urease activity of Helicobacter pylori. The active compounds were isolated from the extract of Forsythia suspense VAHL. Two active compounds, betulinic acid and oleanolic acid, were found in the extract. At the same concentration level, betulinic acid inhibited urease activity of $H$. pylori stronger than oleanolic acid.

\section{Antimalarial Activity}

The in vitro and in vivo antimalarial activity of betulinic acid was investigated [39]. Betulinic acid was isolated from an ethanol extract of the root bark of the Tanzanian tree Uapaca nitida Müll-Arg. (Euphorbiaceæ). The in vitro antiplasmodial $\mathrm{IC}_{50}$ values of betulinic acid against chloroquine resistant (K1) and sensitive (T9-96) Plasmodium falciparum were found to be $19.6 \mu \mathrm{g} / \mathrm{ml}$ and 25.9 $\mu \mathrm{g} / \mathrm{ml}$, respectively. Betulinic acid was also tested for in vivo activity in a murine malaria model $(P$. berghei). It was found that the top dosage employed of $250 \mathrm{mg} / \mathrm{kg}$ /day is ineffective at reducing parasitaemia.

Bringmann et al. [5] was isolated betulinic acid from the Triphyophyllum peltatum and Ancistrocladus heyneanus. In vitro antimalarial activity of betulinic acid was tested against asexual erythrocytic stages of the human malaria parasite Plasmodium falciparum. Betulinic acid showed the antimalarial activity between of moderate to good.

\section{Other Biological Activities}

Zhang et al. [40] isolated betulinic acid from the ethanol extract of Tovomita krukovii. They found that betulinic acid shows inhibitory effects against Candida albicans secreted aspartic proteases (SAP) with $\mathrm{IC}_{50}$ values of 6.5 $\mu \mathrm{g} / \mathrm{ml}$. 
Enwerem et al. [10] examined the anthelmintic activity of the methanol, hexane and ethyl acetate extracts of the stem bark of Berlina grandiflora. The ethyl acetate extract was found to be the most active. The isolated betulinic acid from the ethyl acetate fraction at 100 and $500 \mathrm{ppm}$ showed stronger anthelmintic activities than piperazine.

Krogh et al. [41] was isolated betulinic acid from a medicinal plant Ipomoea pes-caprae (L.) R. Br. The results demonstrated that betulinic acid shows pronounced antinociceptive properties in the writhing test and formalin test in mic.

Betulinic acid was isolated from Diospyros leucomelas and was tested for anti-inflammatory activity in the carrageenan and serotonin paw edema and TPA and EPP ear edema [26]. The results showed that betulinic acid is the most affected.

The antifeedant activity of isolated betulinic acid from the leaves of Vitex negundo L. was studied against the third instar larvae of castor semilooper (Achoea janata) [42]. The percentage feeding reduction, at a dosage of 10 $\mu \mathrm{g} / \mathrm{cm}^{2}$, for betulinic acid was $71.18 \%, 84.75 \%$ and $73.34 \%$ after 24,48 and $72 \mathrm{hr}$ time period, respectively.

Betulinic acid was isolated from the methyl ethyl ketone extract of Tetracera boiviniana and was monitored for DNA polymerase $\beta$ inhibition [43]. Betulinic acid showed an inhibition of DNA polymerase $\beta$ with $\mathrm{IC}_{50}$ value of $14 \mu \mathrm{M}$ in the presence of bovine serum albumin (BSA) and $6.5 \mu \mathrm{M}$ in the absence of BSA.

Domínguez-Carmona et al. [44] isolated betulinic acid from the crude extract of the leaves of Pentalinon andrieuxii (Apocynaceae). They tested betulinic acid for its antiprotozoal activity against Leishmania amazonensis (LA), Leishmania braziliensis (M2903), Trypanosoma cruzi tulahuen (TULA) and Plasmodium falciparum (F32). Betulinic acid showed a moderate trypanocidal activity against $\mathrm{T}$. cruzi with $\mathrm{IC}_{50}$ value of $50.0 \mu \mathrm{M}$ and a good antiplasmodial activity with $\mathrm{IC}_{50}$ value of $22.5 \mu \mathrm{M}$ against $P$. falciparum. No any leishmanicidal activity was detected for betulinic acid against L. amazonensis and L. braziliensis.

Betulinic acid was isolated from the $\mathrm{MeOH}$ extract of the roots of Saussurea lappa C. B. Clarke (Compositae) and was evaluated in vitro for protein tyrosine phosphatase 1B (PTP1B) inhibitory activity [45]. Betulinic acid inhibited PTP1B activity with $\mathrm{IC}_{50}$ value of 0.7 $\mu \mathrm{g} / \mathrm{ml}$, which was comparable to those of ursolic acid and RK-682 used as positive controls.

Substantial amounts of betulinic acid was obtained from the stem barks of five Uapaca species (Euphorbiaceae) include Uapaca acuminata, Uapaca guineensis, Uapaca heudolotti, Uapaca paludosa and Uapaca vandhoutei [46]. Isolated betulinic acid was screened in vitro for inhibitory activity against Trypanosoma brucei gly- colytic enzyme GAPDH. Betulinic acid inhibited $T$. brucei GAPDH with an $\mathrm{IC}_{50}$ value of $240 \mu \mathrm{M}$ and was a competitive reversible inhibitor of this enzyme with respect to its cofactor $\mathrm{NAD}^{+}$.

Betulinic acid was obtained from the dried and powdered roots of Clusia nemorosa L. (Clusiaceae) and was tested for its antiobese activity in the adult male Swiss mice on a high-fat diet (HFD) [47]. It was found that mice treated with betulinic acid $(50 \mathrm{mg} / \mathrm{L}$, in drinking water) and fed a HFD showed significantly decreased body weights, abdominal fat accumulation, blood glucose, plasma triglycerides, and total cholesterol relative to their respective controls fed no betulinic acid during 15 weeks. It was suggested that betulinic acid has an antiobese potential through modulation of fat and carbohydrate metabolism.

Betulinic acid was isolated and identified from the methanolic extract of the stem bark of Clusia ellipticifolia and was studied for its antinociceptive activity [48]. The pharmacological study using the abdominal contortions model induced by acetic acid showed significant antinociceptive activities to the isolated compounds and the highest effect was attributed to the betulinic acid.

Betulinic acid was isolated from the powdered rose hip with and without fruits (Rosae pseudofructus cum/sine fructibus, Rosa canina L., Rosaceae) and was tested in vitro for inhibition of cyclooxygenase (COX-1, COX-2) and 5-LOX-mediated leukotriene $\mathrm{B}_{4}\left(\mathrm{LTB}_{4}\right)$ formation [49]. Betulinic acid was found to act as moderate inhibitors of COX-1, COX-2 and LT formation in vitro with $\mathrm{IC}_{50}$ values of $>125,>125$ and $102.2 \mu \mathrm{M}$, respectively.

\section{REFERENCES}

[1] Y. Kashiwada, H. K. Wang, T. Nagao, S. Kitanaka, I. Yasuda, T. Fujioka, T. Yamagishi, L. M, Cosentino, M. Kozuka, H. Okabe, Y. Ikeshiro, C. Q. Hu, E. Yeh and K. H. Lee, "Anti-AIDS Agents. 30. Anti-HIV Activity of Oleanolic Acid, Pomolic Acid, and Structurally Related Triterpenoids," Journal of Natural Products, Vol. 61, No. 9, pp. 1090-1095. doi:10.1021/np9800710

[2] T. Fujioka, Y. Kashiwada, R. E. Kilkuskie, L. M. Cosentino, L. M. Ballas, J. B. Jiang, W. P. Janzen, I. S. Chen and K. H. Lee, "Anti-AIDS Agents, 11. Betulinic Acid and Platanic Acid as Anti-HIV Principles from Syzygium Claviflorum, and the Anti-HIV Activity of Structurally Related Triterpenoids," Journal of Natural Products, Vol. 57, No. 2, 1994, pp. 243-247. doi: $10.1021 / \mathrm{np} 50104 \mathrm{a} 008$

[3] C. Chandramu, R. D. Manohar, D. G. Krupadanam and R. V. Dashavantha, "Isolation, Characterization and Biological Activity of Betulinic Acid and Ursolic Acid from Vitex negundo L," Phytotherapy Research, Vol. 17, No. 2, 2003, pp. 129-134. doi:10.1002/ptr.1088

[4] G. Bringmann, W. Saeb, L. A. Assi, G. Francois, A. S. S. Narayanan, K. Peters and E. M. Peters, "Betulinic Acid: 
Isolation from Triphyophyllum peltatum and Ancistrocladus heyneanus, Antimalarial Activity, and Crystal Structure of the Benzyl Ester," Planta Medica, Vol. 63, No. 3, 1997, pp. 255-257. doi:10.1055/s-2006-957666

[5] S. Alakurtti, T. Mäkelä, S. Koskimies and Y. J. Kauhaluoma, "Pharmacological Properties of the Ubiquitous Natural Product Botulin," European Journal of Pharmaceutical Sciences, Vol. 29, No. 1, 2006, pp. 1-13. doi:10.1016/j.ejps.2006.04.006

[6] P. Bernard, T. Scior, B. Didier, M. Hibert and J. Berthon, "Ethnopharmacology and Bioinformatic Combination for Leads Discovery: Application to Phospholipase A2 Inhibitors," Phytochemistry, Vol. 58, No. 6, 2001, pp. 865874. doi:10.1016/S0031-9422(01)00312-0

[7] A. I. Huguet, M. D. C. Recio, S. Manez, R. M. Giner and J. L. Rios, "Effect of Triterpenoids on the Inflammation Induced by Protein Kinase C Activators, Neuronally Acting Irritants and Other Agents," European Journal of Pharmacology, Vol. 410, No. 1, 2000, pp. 69-81. doi:10.1016/S0014-2999(00)00860-8

[8] P. K. Mukherjee, K. Saha, J. Das, M. Pal and B. P. Saha, "Studies on the Anti-Inflammatory Activity of Rhizomes of Nelumbo Nucifera," Planta Medica, Vol. 63, No. 4, 1997, pp. 367-369. doi:10.1055/s-2006-957705

[9] N. M. Enwerem, J. I. Okogun, C. O. Wambebe, D. A. Okorie and P. A. Akah, "Anthelmintic Activity of the Stem Bark Extracts of Berlina Grandiflora and One of Its Active Principles, Betulinic Acid," Phytomedicine, Vol. 8, No. 2, 2001, pp. 112-114. doi:10.1078/0944-7113-00023

[10] K. Kinoshita, M. Akiba, M. Saitoh, Y. Ye, K. Koyama, K. Takahashi, N. Kondo and H. Yuasa, "Antinociceptive Effect of Triterpenes from Cacti," Pharmaceutical Biology, Vol. 36, No. 1, 1998, pp. 50-57. doi:10.1076/phbi.36.1.50.4614

[11] S. Y. Ryu, C. K. Lee, J. W. Ahn, S. H. Lee and O. P. Zee, "Antiviral Activity of Triterpenoid Derivatives," Archives of Pharmacal Research, Vol. 16, No. 4, 1993, pp. 339342. doi:10.1007/BF02977528

[12] S. Y. Ryu, C. K. Lee, C. O. Lee, H. S. Kim and O. P. Zee, "Antiviral Triterpenes from Prunella vulgaris," Archives of Pharmacal Research, Vol. 15, No. 3, 1992, pp. 242245. doi:10.1007/BF02974063

[13] V. Zuco, R. Supino, S. C. Righetti, L. Cleris, E. Marchesi, C. Gambacorti-Passerini and F. Formelli, "Selective Cytotoxicity of Betulinic Acid on Tumor Cell Lines, but Not on Normal Cells," Cancer Letters, Vol. 175, No. 1, 2002, pp. 17-25. doi:10.1016/S0304-3835(01)00718-2

[14] S. Fulda and K. M. Debatin, "Betulinic Acid Induces Apoptosis through a Direct Effect on Mitochondria in Neuroectodermal Tumors," Medical and Pediatric Oncology, Vol. 35, No. 6, 2000, pp. 616-618. doi:10.1002/1096-911X(20001201)35:6<616::AID-MPO 27>3.0.CO;2-N

[15] S. Fulda, I. Jeremias, H. H. Steiner, T. Pietsch and K. M. Debatin, "Betulinic Acid: A New Cytotoxic Agent against Malignant Brain-Tumor Cells," International Journal of Cancer, Vol. 82, No. 3, 1999, pp. 435-441. doi:10.1002/(SICI)1097-0215(19990730)82:3<435::AID$\underline{\mathrm{IJC} 18>3.0 . \mathrm{CO} ; 2-1}$
[16] E. Pisha, H. Chai, I. S. Lee, T. E. Chagwedera, N. R. Farnsworth, A. C. Cordell, C. W. W. Beecher, H. H. H. Fong, A. D. Kinghorn, D. M. Brown, M. C. Wani, M. E. Wall, T. J. Hieken, T. K. Das Gupta and J. M. Pezzuto, "Discovery of Betulinic Acid as a Selective Inhibitor of Human Melanoma That Functions by Induction of Apoptosis," Nature Medicine, Vol. 1, No. 10, 1995, pp. 10461051. doi:10.1038/nm1095-1046

[17] R. H. Cichewicz and S. A. Kouzi, "Chemistry, Biological Activity, and Chemotherapeutic Potential of Betulinic Acid for the Prevention and Treatment of Cancer and HIV Infection," Medicinal Research Reviews, Vol. 24, No. 1, 2004, pp. 90-114. doi:10.1002/med.10053

[18] T. Galgon, D. Hoke and B. Drager, "Identification and Quantification of Betulinic Acid," Phytochemical Analysis, Vol. 10, No. 4, 1999, pp. 187-190.

doi:10.1002/(SICI)1099-1565(199907/08)10:4<187::AID -PCA443>3.0.CO;2-K

[19] B. J. W. Cole, M. D. Bentley and Y. Hua, "Triterpenoid Extractives in the Outer Bark of Betula lenta (Black Birch)," Holzforschung, Vol. 45, No. 4, 1991, pp. 265 268. doi:10.1515/hfsg. 1991.45.4.265

[20] M. M. O'Connell, M. D. Bently, C. S. Campbell and B. J. W. Cole, "Betulin and Lupeol in Bark from Four WhiteBarked Birches," Phytochemistry, Vol. 27, No. 7, 1988, pp. 2175-2176. doi:10.1016/0031-9422(88)80120-1

[21] W. Schühly, J. Heilmann, I. Callis and O. Sticher, "New Triterpenoids with Antibacterial Activity from Zizyphus joazeiro," Planta Medica, Vol. 65, No. 8, 1999, pp. 740743. doi:10.1055/s-1999-14054

[22] S. G. Jagadeesh, G. L. D. Krupadanam, G. Srimannarayana, S. S. Murthy, A. Kaur and S. S. Raja, "Tobacco Caterpillar Antifeedant from the Gotti Stem Wood Triterpene Betulinic Acid," Journal of Agricultural and Food Chemistry, Vol. 46, No. 7, 1998, pp. 2797-2799. doi:10.1021/jf970768b

[23] C. W. Chang, T. S. Wu, Y. S. Hsieh, S. C. Kuo and P. D. L. Chao, "Terpenoids of Syzygium formosanum," Journal of Natural Products, Vol. 62, No. 2, 1999, pp. 327-328. doi: $10.1021 / \mathrm{np} 980313 \mathrm{w}$

[24] M. Higa, K. Ogihara and S. Yogi, "Bioactive Naphthoquinone Derivatives from Diospyros Maritime Blume," Chemical \& Pharmaceutical Bulletin, Vol. 46, No. 8, 1998, pp. 1189-1193. doi:10.1248/cpb.46.1189

[25] P. Singh and S. Sharma, "Triterpenoid Constituents of the Seed of Diospyros melanoxylon, Tecomella undulata, and Terminalia bellirica," Journal of the Indian Chemical Society, Vol. 74, 1997, pp. 504-505.

[26] M. C. Recio, R. M. Giner, S. Manez, J. Gueho, H. R. Julien, K. Hostettmann and J. L. Rios, "Investigations on the Steroidal Anti-Inflammatory Activity of Triterpenoids from Diospyros leucomelas," Planta Medica, Vol. 61, No. 1, 1995, pp. 9-12. pp. 9-12. doi:10.1055/s-2006-957988

[27] H. C. Lin, H. Y. Ding and Y. C. Wu, "Two Novel Compounds from Paeonia suffruticosa," Journal of Natural Products, Vol. 61, No. 3, 1998, pp. 343-346. doi:10.1021/np9704258

[28] P. A. Krasutsky, "Birch Bark Research and Develop- 
ment," Natural Product Reports, Vol. 23, No. 6, 2006, pp. 919-942. doi:10.1039/b606816b

[29] D. Kumar, S. Mallick, J. R. Vedasiromoni and B. C. Pal, "Anti-Leukemicactivity of Dillenia indica L. Fruit Extract and Quantification of Betulinic Acid by HPLC," Phytomedicine, Vol. 17, No. 6, 2010, pp. 431-435. doi:10.1016/j.phymed.2009.07.010

[30] Y. Tezuka, P. Stampoulis, A. H. Banskota, S. Awale, K. Q. Tran, I. Saiki and S. Kadota, "Constituents of the Vietnamese Medicinal Plant Orthosiphon stamineus," Chemical \& Pharmaceutical Bulletin, Vol. 48, No. 11, 2000, pp. 1711-1714. doi:10.1248/cpb.48.1711

[31] H. Liu, S. Wang, B. Cai and X. Yao, "Anticancer Activity of Compounds Isolated from Engelhardtia serrata Stem Bark," Archives of Physiology and Biochemistry, Vol. 42, No. 7, 2004, pp. 475-477. doi:10.1080/13880200490889028

[32] S. I. Wada and R. Tanaka, "Betulinic Acid and Its Derivatives, Potent DNA Topoisomerase II Inhibitors, from the Bark of Bischofia javanica," Chemistry \& Biodiversity, Vol. 2, No. 5, 2005, pp. 689-694. doi:10.1002/cbdv.200590045

[33] L. Fu, S. Zhang, N. Li, J. Wang, M. Zhao, J. Sakai, T. Hasegawa, T. Mitsui, T. Kataoka, S. Oka, M. Kiuchi, K. Hirose and M. Ando, "Three New Triterpenes from Nerium oleander and Biological Activity of the Isolated Compounds," Journal of Natural Products, Vol. 68, No. 2, 2005, pp. 198-206. doi:10.1021/np040072u

[34] A. Theo, T. Masebe, Y. Suzuki, H. Kikuchi, S. Wada, C. L. Obi, P. O. Bessong, M. Usuzawa, Y. Oshima and T. Hattori, "Peltophorum Africanum, a Traditional South African Medicinal Plant, Contains an Anti HIV-1 Constituent, Betulinic Acid," Tohoku Journal of Experimental Medicine, Vol. 217, No. 2, 2009, pp. 93-99. doi:10.1620/tjem.217.93

[35] V. Reutrakul, W. Chanakul, M. Pohmakotr, T. Jaipetch, C. Yoosook, J. Kasisit, C. Napaswat, T. Santisuk, S. Prabpai, P. Kongsaeree and P. Tuchinda,"Anti-HIV-1 Constituents from Leaves and Twigs of Cratoxylum arborescens," Planta Medica, Vol. 72, No. 15, 2006, pp. 1433-1435. doi:10.1055/s-2006-951725

[36] G. M. Woldemichael, M. P. Singh, W. M. Maiese and B. N. Z. Timmermann, "Constituents of Antibacterial Extract of Caesalpinia paraguariensis Burk," Zeitschrift für Natur for Schung C, Vol. 58, No. 1-2, 2003, pp. 70-75.

[37] W. N. Setzer, M. C. Setzer, R. B. Bates and B. R. Jackes, "Biologically Active Triterpenoids of Syncarpia glomulifera Bark Extract from Paluma, North Queensland, Australia," Planta Medica, Vol. 66, No. 2, 2000, pp. 176177. doi:10.1055/s-2000-11129

[38] S. Shin, C. E. Park, N. I. Baek, I. C. Chung and C. H. Park, "Betulinic and Oleanolic Acids Isolated from Forsythia suspensa VAHL Inhibit Urease Activity of Helicobacter pylori," Biotechnology and Bioprocess Engineering, Vol. 14, No. 2, 2009, pp. 140-145. doi:10.1007/s12257-008-0272-4

[39] J. C. Steele, D. C. Warhurst, G. C. Kirby and M. S. Simmonds, "In Vitro and in Vivo Evaluation of Betulinic
Acid as an Antimalarial," Phytotherapy Research, Vol. 13, No. 2, 1999, pp. 115-119. doi:10.1002/(SICI)1099-1573(199903)13:2<115::AID-PT R404>3.0.CO;2-1

[40] Z. Zhang, H. N. Elsohly, M. R. Jacob, D. S. Pasco, L. A. Walker and A. M. Clark, "Natural Products Inhibiting Candida albicans Secreted Aspartic Proteases from Tovomita krukovii," Planta Medica, Vol. 68, No. 1, 2002, pp. 49-54. doi:10.1055/s-2002-20049

[41] R. Krogh, R. Kroth, C. Berti, A. O. Madeira, M. M. Sourza, V. Cechinel-Felho, F. Delle-Monache and R. A. Yunes, "Isolation and Identification of Compounds with Antinociceptive Action from Ipomoea pes-caprae (L.) R. Br.," Pharmazie, Vol. 54, No. 6, 1999, pp. 464-466.

[42] C. Chandramu, R. D. Manohar, D. G. Krupadanam and R. V. Dashavantha, "Isolation, Characterization and Biological Activity of Betulinic Acid and Ursolic Acid from Vitex negundo L.," Phytotherapy Research, Vol. 17, No. 2, 2003, pp. 129-134. doi:10.1002/ptr.1088

[43] J. Ma, S. R. Starck and S. M. Hecht, "DNA Polymerase $\beta$ Inhibitors from Tetracera boiviniana," Journal of $\mathrm{Na}$ tural Products, Vol. 62, No. 12, 1999, pp. 1660-1663. doi:10.1021/np990326p

[44] D. B. Domínguez-Carmona, F. Escalante-Erosa, K. García-Sosa, G. Ruiz-Pinell, D. Gutierrez-Yapu, M. J. ChanBacab, A. Giménez-Turba and L. M. Peña-Rodríguez, "Antiprotozoal Activity of Betulinic Acid Derivatives," Phytomedicine, Vol. 17, No. 5, 2010, pp. 379-382. doi:10.1016/j.phymed.2009.08.002

[45] J. Y. Choi, M. Na, I. H. Hwang, S. H. Lee, E. Y. Bae, B. Y. Kim and J. S. Ahn, "Isolation of Betulinic Acid, Its Methyl Ester and Guaiane Sesquiterpenoids with Protein Tyrosine Phosphatase 1B Inhibitory Activity from the Roots of Saussurea lappa C. B. Clarke," Molecules, Vol. 14 , No. 1, 2009, pp. 266-272. doi:10.3390/molecules 14010266

[46] B. Nyasse, J. J. Nono, Y. Nganso, I. Ngantchou and B. Schneider, "Uapaca genus (Euphorbiaceae), a Good Source of Betulinic Acid," Fitoterapia, Vol. 80, No. 1, 2009, pp. 32-34. doi:10.1016/j.fitote.2008.09.005

[47] C. L. De Melo, M. G. R. Queiroz, A. C. V. A. Filho, A. M. Rodrigues, D. F. De Sousa, J. G. L. Almeida, O. D. L. Pessoa, E. R. Silveira, D. B. Menezes, T. S. Melo, F. A. Santos and A. V. S. Rao, "Betulinic Acid, a Natural Pentacyclic Triterpenoid, Prevents Abdominal Fat Accumulation in Mice Fed a High-Fat Diet," Journal of Agricultural and Food Chemistry, Vol. 57, No. 19, 2009, pp. 8776-8781. doi:10.1021/jf900768w

[48] A. M. Salama, S. Gamboa and G. Buitrago, "Antinociceptive Activity of Triterpens Isolated from Clusia ellipticifolia," Revista Colombiana de Ciencias Quimico Farmaceuticas, Vol. 33, No. 2, 2004, pp. 156-162.

[49] E. M. Wenzig, U. Widowitz, O. Kunert, S. Chrubasik, F. Bucar, E. Knauder and R. Bauer, "Phytochemical Composition and in Vitro Pharmacological Activity of Two Rose Hip (Rosa canina L.) Preparations," Phytomedicine, Vol. 15, No. 10, 2008, pp. 826-835. doi:10.1016/j.phymed.2008.06.012 